\title{
Purification and characterization of 2-oxoglutarate decarboxylase of Leuconostoc oenos
}

\author{
RAINer KAPOL and Ferdinand RADLeR* \\ Institut für Mikrobiologie und Weinforschung der Johannes Gutenberg-Universität Mainz, Postfach 3980, \\ D-6500 Mainz, FRG
}

(Received 30 November 1989; revised 21 March 1990; accepted 2 April 1990)

2-Oxoglutarate decarboxylase from the lactic acid bacterium Leuconostoc oenos was purified by precipitation with PEG and ion-exchange chromatography. The strictly thiamin-pyrophosphate-dependent enzyme decarboxylated 2-oxoglutarate to succinic semialdehyde. Oxalacetate was metabolized to a lesser extent. The measured $K_{\mathrm{m}}$ values for 2-oxoglutarate and thiamin pyrophosphate were $1 \mathrm{mM}$ and $0.03 \mathrm{mM}$ respectively. The enzyme had a molecular mass in the range 65-70 kDa, did not consist of subunits and showed significant similarities to the corresponding mitochondrial enzyme of Euglena gracilis.

\section{Introduction}

Leuconostoc oenos is the main organism that causes the malolactic fermentation of wine. Besides decarboxylating malic acid, L. oenos metabolizes sulphur-dioxidebinding compounds such as acetaldehyde, pyruvate and 2-oxoglutarate (Mayer et al., 1976). Whereas 2-oxoglutarate is usually reduced to 2-hydroxyglutarate by most lactic acid bacteria, a decarboxylation caused by $L$.oenos leads to the final products 4-hydroxybutyrate and succinate (Radler \& Bröhl, 1984). A specific 2-oxoglutarate decarboxylase has been detected in cell extracts of $L$. oenos (Kapol et al., 1990). This enzyme is presumed to decarboxylate 2-oxoglutarate to succinic semialdehyde. This rather unstable product is reduced by a dehydrogenase to 4-hydroxybutyrate in the presence of a hydrogen donor. In the absence of a hydrogen donor the final products are 2-hydroxyglutarate and succinate in a ratio of $1: 1$. The 2-oxoglutarate decarboxylase is dependent on TPP and is inducible by 2-oxoglutarate (Kapol et al., 1990).

In this paper a method for the purification of 2oxoglutarate decarboxylase from $L$. oenos B 211 is described and the main characteristics of this enzyme are reported.

\section{Methods}

Micro-organism and preparation of cell extracts. L. oenos strain B 211 was from the collection of this Institute. Methods for cultivation, preparation of cell extracts, and protein determination were as described previously (Kapol et al., 1990).

Abbreviation: TPP, thiamin pyrophosphate.
Determination of the activity of 2-oxoglutarate decarboxylase. The carbon dioxide released from 2-oxoglutarate was measured manometrically at $30^{\circ} \mathrm{C}$. The main vessel contained : $0 \cdot 1 \mathrm{ml}$ cell extract $; 0 \cdot 1 \mathrm{ml}$ thiamin pyrophosphate (TPP, $50 \mathrm{mM} ; \mathrm{pH} 5 \cdot 3$ ) $; 2 \mathrm{ml}$ buffer [composed of potassium phosphate buffer (100 mM, pH 5.3); magnesium sulphate ( $2 \mathrm{mM})$; dithiothreitol ( $1 \mathrm{mM})$; glycerol $(30 \% \mathrm{v} / \mathrm{v})]$. To start the reaction $0.2 \mathrm{ml}$ 2-oxoglutarate $(0.5 \mathrm{M}, \mathrm{pH} 5.3)$ was added from the side arm. The reaction was stopped with $0.1 \mathrm{ml} 7 \mathrm{M}$-sulphuric acid added from the second side arm. One unit (U) of 2-oxoglutarate decarboxylase is the amount required to catalyse the release of $1 \mu \mathrm{mol} \mathrm{CO} \mathrm{Cmin}^{-1}$.

For the determination of the $\mathrm{pH}$ optimum and the stability of 2 oxoglutarate decarboxylase the following buffers $(100 \mathrm{mM})$ were used sodium citrate/disodium hydrogen phosphate $(\mathrm{pH} \mathrm{3 \cdot 5-6.0)}$; potassium dihydrogen phosphate/disodium hydrogen phosphate ( $\mathrm{pH} 5 \cdot 2-8 \cdot 2)$ and Tris/ $\mathbf{H C l}$ ( $\mathrm{pH} 7 \cdot 1-8 \cdot 7)$. To these buffers were added (final concentrations): $\mathrm{MgSO}_{4}$ (5 mM); dithiothreitol (1 mM); TPP (4 mM), and glycerol $(30 \%, v / v)$.

Purification of 2-oxoglutarate decarboxylase. To precipitate nucleic acids, protamine sulphate (salmine; $0.2 \mathrm{mg}$ per $\mathrm{mg}$ protein) was added to the cell extract. After stirring for $10 \mathrm{~min}$ at $20^{\circ} \mathrm{C}$ the sediment was removed by centrifugation $\left(45 \mathrm{~min}, 40000 \mathrm{~g}, 4^{\circ} \mathrm{C}\right.$ ). To $3 \mathrm{ml}$ of the supernatant, $1 \mathrm{ml} 50 \%(\mathrm{w} / \mathrm{v})$ polyethylene glycol (PEG) 1500 was added and the mixture was vigorously shaken. After $18 \mathrm{~h}$ at $4{ }^{\circ} \mathrm{C}$ the sediment was collected by centrifuging $(60 \mathrm{~min}, 40000 \mathrm{~g})$ and dissolved in buffer solution [ $20 \mathrm{mM}$-potassium phosphate buffer, $\mathrm{pH} 6 \cdot 7$, containing $0.5 \mathrm{~mm}$-dithiothreitol and $20 \%(\mathrm{v} / \mathrm{v})$ glycerol]. This enzyme solution (about $6 \mathrm{ml}$ ) was applied to a column of DEAE-cellulose (23 SS Servacel $)(2.6 \times 26 \mathrm{~cm})$ that had been equilibrated with buffer solution. Unbound proteins were washed out with $150 \mathrm{ml}$ buffer solution. 2-Oxoglutarate decarboxylase was specifically eluted with $60-80 \mathrm{ml}$ $20 \mathrm{~mm}$ potassium phosphate buffer, pH 6.3, containing $10 \mathrm{~mm}-2$ oxoglutarate. 2-Oxoglutarate decarboxylase was the first protein to be eluted with this buffer. Only inactive proteins were eluted at $\mathrm{pH}$ values below $6 \cdot 3$.

Analytical methods. For isoelectric focusing the Rotofor system (BioRad) was used. To the samples $(220 \mathrm{mg}$ protein in $20 \mathrm{ml}$ ), $20 \mathrm{~mm}$ potassium phosphate buffer, pH 6.7 , containing $30 \%(\mathrm{v} / \mathrm{v})$ glycerol, 
was added to give a total volume of $40 \mathrm{ml}$. Ampholine solutions $(1.6 \mathrm{ml}$ pH 3-5, and 0.4 ml pH 3-10) were added before focusing for $4.5 \mathrm{~h}$ at $4{ }^{\circ} \mathrm{C}$ with a current limited to a maximum of $12 \mathrm{~W}$ and $2000 \mathrm{~V}$. Pharmacia equipment was used for SDS-PAGE (similar to the method of Weber \& Osborn, 1969) and non-denaturing PAGE (as described by Caspritz \& Radler, 1983). 2-Oxoglutarate and the reaction products were determined by HPLC (Pfeiffer \& Radler, 1985).

Chemicals. Ampholines and protein molecular mass kits were from Pharmacia. 2-Oxoglutarate was obtained from Roth and Servacel DEAE-cellulose $23 \mathrm{SS}$ was from Serva. All other chemicals, including PEG 1500, were purchased from Merck.

\section{Results and Discussion}

\section{Purification of 2-oxoglutarate decarboxylase}

From extracts of cells of $L$. oenos B 211 grown in the presence of 2-oxoglutarate, the inducible 2-oxoglutarate decarboxylase was purified 420 -fold with a yield of $16 \%$. The preparation was homogeneous on SDS-PAGE. A typical purification is presented in Table 1 .

\section{Characteristics of 2-oxoglutarate decarboxylase}

Stability. In cell extracts to which glycerol $(30 \%, \mathrm{v} / \mathrm{v})$ and TPP (5 mM) had been added, the activity of 2oxoglutarate decarboxylase remained unchanged for at least $6 \mathrm{~d}$ at $4{ }^{\circ} \mathrm{C}$ or several months at $-20^{\circ} \mathrm{C}$. Purified preparations lost activity rapidly; after $24 \mathrm{~h}$ at $4{ }^{\circ} \mathrm{C}$ or $-20{ }^{\circ} \mathrm{C}$, activity loss was $95 \%$ and $25 \%$ respectively. When extracts adjusted to pH 5.3 were kept at $60{ }^{\circ} \mathrm{C}$, only $10 \%$ of the activity was lost after $30 \mathrm{~min}$, but $90 \%$ was lost after $5 \mathrm{~min}$ at $70^{\circ} \mathrm{C}$. When partially purified preparations of 2-oxoglutarate decarboxylase were kept at various $\mathrm{pH}$ values for $24 \mathrm{~h}$ at $4{ }^{\circ} \mathrm{C}$, the enzyme was stable between $\mathrm{pH} 4 \cdot 6$ and $8 \cdot 2$.

Molecular mass. When the purified enzyme was subjected to PAGE a molecular mass of $70 \mathrm{kDa}$ was calculated. With SDS-PAGE a molecular mass of $65 \mathrm{kDa}$ was determined, indicating that the enzyme does not dissociate into subunits.
Substrate specifity. Whereas pyruvate, malate, lactate, propionate, tartrate and succinate were not substrates for the enzyme, oxalacetate was decarboxylated with a relative activity of $28 \%$ when compared with 2oxoglutarate.

Kinetics. From a Lineweaver-Burk plot the $K_{\mathrm{m}}$ of 2oxoglutarate decarboxylase for 2-oxoglutarate was determined as $1 \mathrm{mM}$. $V$ was determined as $1.3 \mu \mathrm{mol} \mathrm{CO}_{2}$ $\min ^{-1}(\text { mg protein })^{-1}$.

Coenzymes. TPP was essential for the decarboxylation of 2-oxoglutarate. After dialysis for $6 \mathrm{~h}$ in 100 vols $100 \mathrm{mM}$ potassium phosphate buffer, $\mathrm{pH} 7 \cdot 0$, containing $30 \%$ (v/v) glycerol, and then in another 100 vols of the same buffer overnight at $4{ }^{\circ} \mathrm{C}$, the extracts showed no activity. The activity of 2-oxoglutarate decarboxylase was restored by adding TPP ( $2 \mathrm{mM})$. This coenzyme could not be replaced by NADH, NAD, NADPH, NADP, ATP, ADP or CoA, nor did the addition of these compounds enhance the activity of 2-oxoglutarate decarboxylase in the presence of TPP. The $K_{\mathrm{m}}$ for TPP was $0.03 \mathrm{~mm}$.

pH optimum and pI. 2-Oxoglutarate decarboxylase was active in the $\mathrm{pH}$ range $4 \cdot 0-6 \cdot 5$ with an optimum activity at $\mathrm{pH} 5 \cdot 3$. By isoelectric focusing with the Rotofor the $\mathrm{pI}$ was found to be $4 \cdot 2$.

Influence of dibasic ions. None of the dibasic ions (1 mM) tested activated 2-oxoglutarate decarboxylase. The enzyme activity was not or only very little affected by $\mathrm{Mg}^{2+}, \mathrm{Mn}^{2+}, \mathrm{Ca}^{2+}, \mathrm{Ni}^{2+}, \mathrm{Sn}^{2+}$ or $\mathrm{Ba}^{2+}$. The ions $\mathrm{Co}^{2+}$, $\mathrm{Zn}^{2+}$ and $\mathrm{Fe}^{2+}$ caused an inhibition of up to $50 \%$, whereas $\mathrm{Cu}^{2+}$ and $\mathrm{Hg}^{2+}$ inhibited the enzyme by $91 \%$ and $95 \%$ respectively.

Influence of SH reagents and chelators. 2-Oxoglutarate decarboxylase was activated by dithiothreitol $(40 \%)$ and by mercaptoethanol $(30 \%)$ at $5 \mathrm{~mm}$. The $\mathrm{SH}$ antagonists $N$-ethylmaleimide and $p$-chloromercuribenzoate did not affect the enzyme activity. 2-Oxoglutarate decarboxylase was $84 \%$ inhibited by EDTA at a concentration of $5 \mathrm{mM}$, whereas $o$-phenanthroline caused an inhibition of $39 \%$.

Table 1. Purification of 2-oxoglutarate decarboxylase from L. oenos B 211

\begin{tabular}{lccccc}
\hline \hline \multicolumn{1}{c}{ Fraction } & $\begin{array}{c}\text { Total } \\
\text { protein } \\
(\mathrm{mg})\end{array}$ & $\begin{array}{c}\text { Total } \\
\text { activity } \\
(\mathrm{U})\end{array}$ & $\begin{array}{c}\text { Specific } \\
\text { activity } \\
{[\mathrm{U}(\mathrm{mg} \text { protein) }}\end{array}$ & $\begin{array}{c}\text { Purification } \\
(\text {-fold })\end{array}$ & $\begin{array}{c}\text { Yield } \\
(\%)\end{array}$ \\
\hline Cell extract & 484 & 76 & $0 \cdot 16$ & 1 & 100 \\
Salmine sulphate precipitation & 436 & 76 & $0 \cdot 17$ & $1 \cdot 1$ & 100 \\
PEG 1500 precipitation & 32 & 59 & $1 \cdot 8$ & 11 & 78 \\
DEAE-cellulose 23 SS & 0.18 & 12 & 66 & 420 & 16 \\
\hline \hline
\end{tabular}




\section{General aspects}

2-Oxoglutarate decarboxylase of $L$. oenos was rapidly inactivated in cell extracts but it could be stabilized by adding glycerol and TPP, enabling it to be stored at low temperature for several months. High losses of enzyme activity were encountered during the purification procedure and it was important to use as few steps as possible. The essential step was an unusual 'affinity elution' of 2oxoglutarate decarboxylase from DEAE-cellulose 23 SS by slightly lowering the $\mathrm{pH}$ of the eluant and adding 2 oxoglutarate. This procedure led to a homogeneous enzyme preparation using only a few steps. It is not likely that 2-oxoglutarate caused a simple neutralization of the charged molecules, as has been observed with fructose1,6-bisphosphate aldolase (Pogell, 1962) or fructose-1,6bisphosphatase (Black et al., 1972), for under the experimental conditions the enzyme and the substrate were negatively charged. It can be assumed that 2oxoglutarate decarboxylase changes its conformational structure when 2-oxoglutarate is bound. This may alter its affinity for the column material. Such conformational changes affecting the interaction between protein and column material have been described with several enzymes (Bennet \& Steitz, 1978; Pickover et al., 1979).

The activity of 2-oxoglutarate decarboxylase was first observed in several strains of L. oenos (Radler \& Bröhl, 1984). Subsequently this enzyme was detected in mitochondria of Euglena gracilis Z (Shigeoka et al., 1986). The 2-oxoglutarate decarboxylases from $E$. gracilis and $L$.oenos have common characteristics : both enzymes are TPP specific; the end products of the decarboxylation of 2-oxoglutarate are succinic semialdehyde and $\mathrm{CO}_{2}$; and oxalacetate is decarboxylated, but to a lesser extent than 2-oxoglutarate.

In $E$. gracilis, 2-oxoglutarate decarboxylase replaces the missing 2-oxoglutarate dehydrogenase complex, thus maintaining part of the tricarboxylic acid cycle. The biological significance of 2-oxoglutarate decarboxylase in $L$. oenos is not known. It can be assumed that the reaction product succinic semialdehyde acts as a sink for hydrogen equivalents. This may be energetically favourable under anaerobic conditions. However, no significant increase in biomass is observed when 2-oxoglutarate is metabolized by L. oenos (F. Radler, unpublished). Most lactic acid bacteria reduce 2-oxoglutarate to 2hydroxybutyrate; obviously 2-oxoglutarate dehydrogenase is missing in L. oenos.

\section{References}

BenNeT, W. S. \& STeitz, T. A. (1978). Glucose-induced conformational change in yeast hexokinase. Proceedings of the National Academy of Sciences of the United States of America 75, 4748-4752.

Black, W. S., van Tol, A., Fernando, S. \& Horecker, B. L. (1972). Isolation of a highly active fructose diphosphatase from rabbit muscle: its subunit structure and activation by monovalent cations. Archives of Biochemistry and Biophysics 151, 576-590.

CASPRITZ, G. \& RADLER, F. (1983). Malolactic enzyme of Lactobacillus plantarum. Purification, properties and distribution among bacteria. Journal of Biological Chemistry 258, 4907-4910.

KAPOL, R., STORCK, J. \& RADleR, F. (1990). 2-Oxoglutarate decarboxylase of Leuconostoc oenos. Folia Microbiologica 35 (in the Press).

Mayer, K., Pause, G. \& Vetsch, U. (1976). Gehalte an $\mathrm{SO}_{2}-$ bindenden Stoffen in Wein: Einfluss von Gärung und biologischem Säureabbau. Schweizerische Zeitschrift für Obst- und Weinbau 112, 309-313.

PFeIFFER, P. \& RADLER, F. (1985). Hochleistungsflüssig-chromatographische Bestimmung von organischen Säuren, Zuckern, Glycerin und Alkohol im Wein an iener Kationenaustauschersäule. Zeitschrift für Lebensmittel-Untersuchung und-Forschung 181, 24-27.

Pickover, C. A., McKay, D. B., Engelman, M. D. \& Steitz, T. A. (1979). Substrate binding closes the cleft between the domains of yeast phosphoglycerate kinase. Journal of Biological Chemistry 254, $11323-11329$.

PoGell, B. N. (1962). Enzyme purification by selective elution with substrate from substituted cellulose columns. Biochemical and Biophysical Research Communications 7, 225-230.

RADLER, F. \& BRöHL, K. (1984). The metabolism of several carboxylic acids by lactic acid bacteria. Zeitschrift für Lebensmittel-Untersuchung und -Forschung 179, 228-231.

Shigeoka, S., Onishi, T., Maeda, K., Nakano, Y. \& Kitaoka, S. (1986). Occurrence of thiamine pyrophosphate-dependent 2-oxoglutarate decarboxylase in mitochondria of Euglena gracilis. FEBS Letters 195, 43-47.

WEBER, K. \& OSBORN, M. (1969). The reliability of molecular weight determinations by dodecyl sulfate-polyacrylamide gel electrophoresis. Journal of Biological Chemistry 244, 4406-4412. 